\title{
Labyrinthe
}

1 | 1998

Numéro 1

\section{Poèmes en exil}

Traductions du russe par Pavel Chinsky

Anatoly Chteyguer, Guéorgui Adamovitch and Mikhaïl Gorline

\section{(2) OpenEdition}

\section{Journals}

Electronic version

URL: http://journals.openedition.org/labyrinthe/344

DOI: $10.4000 /$ labyrinthe.344

ISSN: 1950-6031

\section{Publisher}

Hermann

\section{Printed version}

Date of publication: 15 October 1998

Number of pages: 117-123

\section{Electronic reference}

Anatoly Chteyguer, Guéorgui Adamovitch and Mikhaïl Gorline, " Poèmes en exil », Labyrinthe [Online],

1 | 1998, Online since 04 March 2005, connection on 03 May 2019. URL : http://

journals.openedition.org/labyrinthe/344 ; DOI : 10.4000/labyrinthe.344

This text was automatically generated on 3 May 2019.

Propriété intellectuelle 


\section{Poèmes en exil}

Traductions du russe par Pavel Chinsky

Anatoly Chteyguer, Guéorgui Adamovitch and Mikhaïl Gorline 